\title{
Children traffic fatalities in Croatia from 2005 until 2016
}

\author{
E. Missoni ${ }^{1, *}, T . J$. Mlinarić ${ }^{1}$, and B. Božić ${ }^{2}$ \\ ${ }^{1}$ Faculty of Transport and Traffic Sciences, University of Zagreb, Vukelićeva 4, 10000, Zagreb, Croatia \\ ${ }^{2}$ Faculty of Medicine in Zagreb, Neurosurgical Department of "Sestre Milosrdnice" Hospital in Zagreb, Croatia
}

\begin{abstract}
The goal of this paper is to investigate and demonstrate the problem of fatalities of Croatian children under the age of 13 near suburban railways. Specific attention will be payed to the manner and conditions in which they are being instructed and accustomed to use this particular means of transport. Concluding remarks indicate that children should be taught from an early age that although using the suburban railways is very effective and has numerous advantages, in can nevertheless pose a safety risk if they do not behave cautiously (especially when getting on and off the train). In this research the authors examine the traffic injury death rates among children in the Republic of Croatia aged 13 and less over a twelve-year period. From 2005 until 2016 a total of 203 children were fatally injured. The most fatalities occurred in 2006 when a total of 26 children were killed, whereupon in 2016 that figure decreased to 2. Although the number of fatally injured children is gradually decreasing, it still gives cause for concern. In addition, over a ten-year period, from 2006 until 2015, a total of 515 children were seriously injured. Most of these injuries occurred in 2006 (98 children injured), while in 2015 there were only 30 injured children. The overall rate of fatal traffic accidents in Croatia of 8.3 (2012) per 100,000 inhabitants is even now at a high level compared to other European countries.
\end{abstract}

\section{Introduction}

We are witnessing an increase in motorisation, growth in the number of vehicles, and ever hastier mobility of traffic participants on a daily basis. Unfortunately, beside all its positive effects, there is also a negative side to increased traffic [1].

Every day thousands of people get killed and injured on roads worldwide. Children and youth go to kindergarten and school, as pedestrians, cyclists, or they drive by car and - sadly never come home, leaving behind grief and pain. Millions of people spend a number of weeks in hospital after serious traffic accidents, after which they are no longer able to lead a normal life, to work and to rejoice, because they remain permanently disabled, becoming a burden on their loved ones. Active participants involved in road traffic make for major factors in accidents [12].

Children in road traffic are defined here as persons aged from 0 to 13 years. Those belonging to age group between 0 and 4 years are considered as babies and toddlers, those between 5 and 10 years are in pre-puberty phase, and those between 11 and 14 are in puberty or early adolescence phase [11].

Each phase within childhood is characterised, and consequently defined, by distinctive levels of physical and psychological skill. Children as road users cannot, therefore, be considered a homogenous group as their abilities and their mode of transport choice differs considerably. Data about the mobility patterns of children as road users in general is rather scarce. In fact, little is known about children under the age of 6 because most of the statistical data starts with children at this age and older.

Within this paper we aim to examine the trends in injury risks for child pedestrians, cyclists and car occupants in Croatia over a twelve-year period, from 2005 until 2016. Motor vehicles crashes are one of the leading causes of death and acquired disability in children from birth to 14 years of age worldwide [1, 2]. For instance, while road traffic crashes account for about 170 child deaths and close to 4000 serious injuries each year in the UK [3], that number astonishingly rises to over 12,000 children fatalities in China [4, 5].

\section{Methods - Data collection and analysis}

All the data presented in this paper have been gathered from police reports of the Traffic Police Department, Ministry of Internal Affairs, Croatia, which were registered on the respective scenes of the accidents.

\footnotetext{
* Corresponding author: missoni@ffpz.hr
} 


\section{Results}

The most child fatalities in Croatia occurred in 2006 when a total of 26 children were killed, whereupon in 2016 that figure had decreased to 2, thus corresponding with an overall declining trend in the number of people killed in road traffic crashes, which had been reduced from the total of 597 in 2005 to 307 in 2016. Although the number of fatally injured children is gradually decreasing, it still gives cause for concern.

Table 1. Crash-related child fatalities in traffic in Croatia from 2005 until 2016 [8].

\begin{tabular}{|c|c|c|c|c|c|c|c|c|c|c|c|c|c|}
\hline & \multicolumn{12}{|c|}{ YEAR } & \multirow[t]{2}{*}{ TOTAL } \\
\hline Age & 2005 & 2006 & 2007 & 2008 & 2009 & 2010 & 2011 & 2012 & 2013 & 2014 & 2015 & 2016 & \\
\hline $\begin{array}{c}0-6 \\
\text { yrs. }\end{array}$ & 10 & 13 & 13 & 8 & 12 & 6 & 4 & 1 & 5 & 3 & 4 & 1 & 96 \\
\hline $\begin{array}{c}7-13 \\
\text { yrs. }\end{array}$ & 8 & 13 & 12 & 9 & 9 & 4 & 9 & 6 & 3 & 5 & 5 & 1 & 97 \\
\hline Total & 18 & 26 & 25 & 17 & 21 & 10 & 13 & 7 & 8 & 8 & 9 & 2 & 203 \\
\hline
\end{tabular}

Table 2. Pedestrian injuries causing death.

\begin{tabular}{|c|c|c|c|c|c|c|c|c|c|c|c|c|c|}
\hline & 2005 & 2006 & 2007 & 2008 & 2009 & 2010 & 2011 & 2012 & 2013 & 2014 & 2015 & 2016 & TOTAL \\
\hline $\begin{array}{c}\mathbf{0 - 1 3} \\
\text { yrs }\end{array}$ & $\mathbf{6}$ & $\mathbf{1 3}$ & $\mathbf{8}$ & $\mathbf{5}$ & $\mathbf{7}$ & $\mathbf{5}$ & $\mathbf{5}$ & $\mathbf{4}$ & $\mathbf{3}$ & $\mathbf{4}$ & $\mathbf{2}$ & $\mathbf{2}$ & $\mathbf{6 4}$ \\
\hline
\end{tabular}

Table 3. Vehicle passengers, injuries causing death.

\begin{tabular}{|c|c|c|c|c|c|c|c|c|c|c|c|c|c|}
\hline & 2005 & 2006 & 2007 & 2008 & 2009 & 2010 & 2011 & 2012 & 2013 & 2014 & 2015 & 2016 & TOTAL \\
\hline $\begin{array}{c}\mathbf{0 - 1 3} \\
\text { yrs }\end{array}$ & $\mathbf{1 1}$ & $\mathbf{1 0}$ & $\mathbf{1 5}$ & $\mathbf{1 1}$ & $\mathbf{1 3}$ & $\mathbf{4}$ & $\mathbf{5}$ & $\mathbf{0}$ & $\mathbf{5}$ & $\mathbf{3}$ & $\mathbf{4}$ & $\mathbf{0}$ & $\mathbf{8 1}$ \\
\hline
\end{tabular}

\section{Discussion}

The rate of fatal traffic accidents in Croatia of 8.3 (2012) per 100,000 inhabitants is even now at a high level relative to other European countries. Seeing as children, pedestrians and cyclists are the most endangered and vulnerable group of traffic participants, their safety deserves special attention. It has been established that when motor vehicle collisions occur, children are best protected when properly using the appropriate restraint and sitting in a rear row [9].

Of the 32,719 traffic fatalities in 2013 in the United States, 1,149 (4\%) were children 14 and younger (National Centre for Statistics and Analysis (NCSA), an office of the United States National Highway Traffic Safety Administration (NHTSA)). In 2013, the 1,149 child traffic fatalities were a $2 \%$ decrease from 1,173 in 2012. In 2013, the estimated 172,000 injured children in traffic crashes were a 2\% increase from 169,000 in 2012. In 2013, motor vehicle traffic crashes were the leading cause of death for children age 4 and the second leading cause of death for children aged 3 and from 5 to 14 years of age (NCSA).

Furthermore, road danger is a strong disincentive to active transport (i.e., walking and cycling) and thus contributes to increasing levels of childhood obesity. Fear of pedestrian injury can create a vicious circle if an increasingly dangerous pedestrian environment encourages greater car use, leading to higher motorized traffic volumes and greater risks to pedestrians [6]. Reducing injury risks for child pedestrians and cyclists would be an important part of any strategy to promote walking and cycling, and might also reduce social class gradients in child injury mortality. Another method of protecting children from crash-related injuries is the use of child passenger safety seats; when correctly installed and used, they can significantly reduce the risk of crashrelated fatalities by up to $71 \%$, and the risk of serious injury by up to $67 \%$ [7]. 


\section{Conclusion}

From the presented data it becomes apparent that most traffic accident involving children occur when they are pedestrians or car passengers. Therefore we recommend and strongly encourage popularisation and further utilisation of suburban railroad as means of transport suitable for children, ensuring their safety. In view of these facts, it becomes clear that there is a pressing need to develop a nationwide strategy in order to reduce traffic injury death rates among children, which should be primarily directed towards professional training of school and preschool teachers.

Promoting correct behaviour among all traffic participants so that they could continuously acquire appropriate traffic knowledge and traffic culture, should continue to be implemented throughout high-school education, and especially at an university level where, for example, students can gain such knowledge during the course of "Traffic Medicine" lectures delivered at the Faculty of Transport and Traffic Sciences, University of Zagreb, Croatia [10, 11].

\section{References}

1. X. Chen, J. Yang, C. Peek-Asa and Liping Li, Parents' experience with child safety restraint in China, BMC Public Health, 14, 318-325 (2014).

2. E. W. Kelli and E. S. Geller, Increasing the safety of children's vehicle travel: From effective risk communication to behavior change, J Safety Res, 35, 263-274 (2004).

3. B. Sonkin, P. Edwards, I. Roberts and J. Green, Walking, cycling and transport safety: An analysis of child road deaths, J R Soc Med, 99, 402-405 (2006).
4. S. Y. Wang, Y. H. Li, G. B. Chi, S. Y. Xiao, J. Ozanne-Smith, M. Stevenson and M. R. Phillips, Injury-related fatalities in China: An underrecognized public-health problem, Lancet, 372, 1765-1773 (2008).

5. X. Zhang, H. Xiang, R. Jing and Z. Tu, Road traffic injuries in the People's Republic of China, 19512008, Traffic Inj Prev, 12, 614-620 (2011).

6. P. L. Jacobsen, Safety in numbers: More walkers and bicyclists, safer walking and bicycling, Injury Prevention, 9, 205-209 (2003).

7. F. K. Winston, D. R. Durbin and M. Kallan, The danger of premature graduation to seat belts for younger children, Pediatrics, 105, 1179-1183 (2000).

8. Ministarstvo Unutarnjih Poslova, Sluţba Za Strateško Planiranje, Analitiku i Razvoj, Statistički Preged. Temeljnih Sigurnosnih Pokazatelja $i$ Rezultata Rada U 2012. Godini,

https://www.mup.hr/UserDocsImages/statistika/201 3/statistika2012.pdf

9. M. M. Macy and G. L. Freed, Child Passenger Safety Practices in the U.S., Disparities in Light of Updated Recommendations, American Journal of Preventive Medicine, 43(3), 272-281 (2012).

10. E. Missoni and I. Missoni, Analiza smrtnih slučajeva djece u prometu u Hrvatskoj, Paediatr Croat, 51, 216-220 (2007).

11. D. Posavec and E. Missoni, Cestovna sigurnost djece $u$ zemljama Europske unije $i$ u Republici Hrvatskoj, Suvremeni promet: časopis za pitanja teorije i prakse prometa, 33, 239-242 (2013).

12. E. Missoni, Ljudski čimbenk u prometu, Sveučilišni udžbenik (FPZ, Zagreb, 2017). 